Article

\title{
Effect of Bridgehead Methyl Substituents on the Gas Permeability of Tröger's-Base Derived Polymers of Intrinsic Microporosity
}

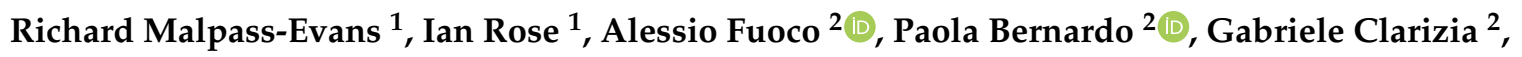 \\ Neil B. McKeown ${ }^{1, *}$, Johannes C. Jansen ${ }^{2, *(D)}$ and Mariolino Carta ${ }^{3, *(D)}$ \\ 1 EaStCHEM, School of Chemistry, University of Edinburgh, Joseph Black Building, David Brewster Road, \\ Edinburgh, Scotland EH9 3FJ, UK; R.Malpass-Evans@ed.ac.uk (R.M.-E.); ianjamesrose@gmail.com (I.R.) \\ 2 Institute on Membrane Technology, CNR-ITM, Via P. Bucci 17/C, 87036 Rende (CS), Italy; \\ a.fuoco@itm.cnr.it (A.F.); p.bernardo@itm.cnr.it (P.B.); g.clarizia@itm.cnr.it (G.C.) \\ 3 Department of Chemistry, College of Science, Swansea University, Grove Building, Singleton Park, Swansea \\ SA2 8PP, UK \\ * Correspondence: Neil.McKeown@ed.ac.uk (N.B.M.); johannescarolus.jansen@cnr.it (J.C.J.); \\ mariolino.carta@swansea.ac.uk (M.C.); Tel.: +44-131-650-4807 (N.B.M.); +39-0984-49-2031 (J.C.J.); \\ +44-01792-604688 (M.C.)
}

Received: 27 February 2020; Accepted: 1 April 2020; Published: 3 April 2020

\begin{abstract}
A detailed comparison of the gas permeability of four Polymers of Intrinsic Microporosity containing Tröger's base (TB-PIMs) is reported. In particular, we present the results of a systematic study of the differences between four related polymers, highlighting the importance of the role of methyl groups positioned at the bridgehead of ethanoanthracene (EA) and triptycene (Trip) components. The PIMs show BET surface areas between $845-1028 \mathrm{~m}^{2} \mathrm{~g}^{-1}$ and complete solubility in chloroform, which allowed for the casting of robust films that provided excellent permselectivities for $\mathrm{O}_{2} / \mathrm{N}_{2}, \mathrm{CO}_{2} / \mathrm{N}_{2}, \mathrm{CO}_{2} / \mathrm{CH}_{4}$ and $\mathrm{H}_{2} / \mathrm{CH}_{4}$ gas pairs so that some data surpass the 2008 Robeson upper bounds. Their interesting gas transport properties were mostly ascribed to a combination of high permeability and very strong size-selectivity of the polymers. Time lag measurements and determination of the gas diffusion coefficient of all polymers revealed that physical ageing strongly increased the size-selectivity, making them suitable for the preparation of thin film composite membranes.
\end{abstract}

Keywords: polymers of intrinsic microporosity (PIMs); Tröger's base; gas separation; membrane

\section{Introduction}

Polymeric gas separation membranes are becoming an increasingly important commercial technology for gas purification as an alternative to more energy-intensive processes [1-4]. At present, membranes are utilised in hydrocarbon processing, hydrogen recovery in the manufacture of ammonia, and the separation of nitrogen from air [5-9]. Gas separation membranes also have potential future applications in hydrogen manufacture [10-12] and pre/post-combustion $\mathrm{CO}_{2}$ capture [13-18], and have proven to be successful for biogas upgrading [19]. A drawback of most polymeric membrane materials is their inverse relationship between selectivity and permeability. This well-known trade-off relationship has limited the use of highly selective commercial materials such as polyimides and polysulfones to small-scale applications, since their low productivity makes the process not economically feasible [20]. To compete with existing technology in large-scale applications, gas separation membranes are required to display both high permeability $\left(P_{x}\right)$ and selectivity $\left(\alpha_{x y}=P_{x} / P_{y}\right)$ for a given gas $(x)$ over another gas $(y)$. Robeson demonstrated that there was an upper limit for this trade-off relation in 
1991 [21], based on transport parameters collected from a large number of polymers for technologically important gas pairs, proposing a semi-empirical 'upper-bound' onto plots of $\log P_{x}$ versus $\log \alpha_{x y}$, which was later confirmed in theoretical studies by Freeman [22]. The advancements in membrane technology convinced Robeson to revisit his studies in 2008 [23] when upper bounds were revised to accommodate new high performing polymers. Upper bounds were further updated for several gas pairs by Pinnau et al. in 2015 [24], and by Comesaña-Gándara et al. in 2019 [25]. The revisions were prompted by the development of Polymers of Intrinsic Microporosity (PIMs) [26-29]. PIMs are composed of highly rigid and contorted monomeric segments, which prevent the efficient packing of polymer chains in the solid state. The large fractional free-volume formed between polymer chains allows access to penetrant gases and high solubility for condensable gases such as $\mathrm{CO}_{2}$. At the same time, the rigid structure with impeded chain mobility enhances the energetic selectivity, resulting in a strong size-sieving character of these polymers [30]. When solvent-cast into films for gas permeability experiments, PIMs were found to combine both high selectivity with high permeabilities providing data that was used to define Robeson's 2008 upper bounds and those proposed in 2015 and 2019.

In 2013, we reported a novel polymerisation method to produce solution-processable PIMs from a range of aromatic diamines using Tröger's Base (TB) chemistry [31-35]. In particular, two polymers-PIM-EA( $\left(\mathrm{Me}_{2}\right)$-TB and PIM-Trip $\left(\mathrm{H}_{2}\right)$-TB - showed exceptional gas separation characteristics at low pressures, with a performance far above the 2008 upper bounds for several gas pairs. This was especially true for gas pairs for which the size-selectivity of the membrane is more important than solubility selectivity, such as $\mathrm{O}_{2} / \mathrm{N}_{2}$ or $\mathrm{H}_{2} / \mathrm{N}_{2}$, owing to the highly rigid structures of these polymers $[29,35]$. While the monomeric units from both polymers have similar bicyclic structures, the reported gas separation characteristics were significantly different. In a previous paper [29], we speculated that the bridge-head methyl groups on the ethanoanthracene unit had an influence on the gas separation process, as molecular axial rotation facilitates transport of larger gas molecules through the otherwise inaccessible free volume elements. Our suggestion was that the intermolecular interaction of the methyl groups of different polymer chains helps increase inter-chain spacing. This leads to a higher BET surface area for PIM-EA( $\left(\mathrm{Me}_{2}\right)-\mathrm{TB}$ compared to the triptycene-based polymer but, at the same time, it also shows that the presence of the bulkier methyl groups somewhat hampers the transport of gas molecules. This behaviour suggests that PIM-Trip $\left(\mathrm{H}_{2}\right)$-TB [36] retains a higher proportion of smaller free volume elements, which is consistent with its enhanced size-sieving properties. The trend is clearly displayed by the relative position of PIM-EA( $\left(\mathrm{Me}_{2}\right)-\mathrm{TB}$ in the Robeson plots, compared to the PIM-Trip $\left(\mathrm{H}_{2}\right)$-TB [29]. While the selectivity of PIM-Trip $\left(\mathrm{H}_{2}\right)$-TB drops with pressure for condensable gas pair $\mathrm{CO}_{2} / \mathrm{CH}_{4}$ [37], a property that may be common for similar TB polymers, the selectivity of less condensable gas pairs such as $\mathrm{O}_{2} / \mathrm{N}_{2}$ and $\mathrm{H}_{2} / \mathrm{N}_{2}$ is expected to maintain its high value over a much wider pressure range.

In this paper, we aim to fully evaluate the effects of the bridgehead methyl substituents on surface area and gas separation properties, in both ethanoanthracene (EA)- and triptycene (Trip)-based TB polymers of intrinsic microporosity (TB-PIMs).

\section{Materials and Methods}

\subsection{General Methods and Equipment}

Commercially available reagents were used without further purification. All reactions using air/moisture sensitive reagents were performed in oven-dried or flame-dried apparatus, under a nitrogen atmosphere. Low-temperature $\mathrm{N}_{2}$ adsorption at $77 \mathrm{~K}$ and $\mathrm{CO}_{2}$ adsorption at $273 \mathrm{~K}$, measured using a Quadrasorb Evo, (Quantachrome, Edinburgh, UK), were used to assess intrinsic microporosity (BET) and pore size distribution (PSD), respectively. The polymers were degassed at $120^{\circ} \mathrm{C}$ under high vacuum overnight prior to analysis. GPC was carried out using a Viscotek GPC Max1000 system equipped with a refractive index detector and two KF-805L Shodex columns at a flow of $1 \mathrm{~mL} \mathrm{~min}{ }^{-1}$ of a dilute solution of the polymer in chloroform. The TGA was performed using the device Thermal 
Analysis SDT Q600 (TA Instruments, West Sussex, UK)) at a heating rate of $10{ }^{\circ} \mathrm{C} / \mathrm{min}$ from room temperature to $1000{ }^{\circ} \mathrm{C} .{ }^{1} \mathrm{H}$ NMR spectra were recorded in the solvent stated using an Avance Bruker DPX $400\left(400 \mathrm{MHz}\right.$ ) or DPX $500(500 \mathrm{MHz})$ instruments, Bruker, UK, with ${ }^{13} \mathrm{C}$ NMR spectra recorded at $100 \mathrm{MHz}$ or $125 \mathrm{MHz}$, respectively.

PIM-EA( $\left(\mathrm{Me}_{2}\right)-\mathrm{TB}$, [35] PIM-EA( $\left.\mathrm{H}_{2}\right)-\mathrm{TB}$, [36] and PIM-Trip $\left(\mathrm{H}_{2}\right)$-TB [29] were prepared according to the reported procedures. PIM-Trip $\left(\mathrm{Me}_{2}\right)$-TB was synthetized for the first time for this study (yield: $83 \%$ ), according to the procedure reported in the supporting information.

Films were prepared by dissolving the PIM $(0.350 \mathrm{~g})$ in chloroform $(20 \mathrm{~mL})$ and allowing solvent to evaporate slowly over $96 \mathrm{~h}$ in a Teflon dish. Prior to the permeability measurements, the films were soaked in methanol for $24 \mathrm{~h}$ to remove residual solvent, and then dried for $24 \mathrm{~h}$ in air.

\subsection{Gas Permeation Measurements}

Gas permeabilities of the TB-PIMs membranes were measured in a constant volume/varying pressure apparatus at $25^{\circ}$. The exposed membrane area in the permeation tests was of $2.14 \mathrm{~cm}^{2}$ and the samples were carefully evacuated and degassed completely before the measurements with the following gases: $\mathrm{He}, \mathrm{H}_{2}, \mathrm{O}_{2}, \mathrm{~N}_{2}, \mathrm{CH}_{4}$ and $\mathrm{CO}_{2}$ (purity of $99.99+\%$, SAPIO, Italy).

The time lag method [38] was applied to the recorded data to determine the gas diffusion coefficient. The permeability coefficient, $P$, is reported in units of Barrer $\left(1\right.$ Barrer $=10^{-10} \mathrm{~cm}^{3}(\mathrm{STP}) \mathrm{cm} \mathrm{cm}^{-2} \mathrm{~s}^{-1}$ $\mathrm{cmHg}^{-1}$ ) and calculated from the following equation, describing the increase in the permeate pressure, $p_{t}$, in pseudo-steady state as a function to time, $t$ :

$$
p_{t}=p_{0}+(d p / d t)_{0} \cdot t+\frac{R T \cdot A}{V_{P} \cdot V_{m}} \cdot \frac{p_{f} \cdot P}{l}\left(t-\frac{l^{2}}{6 D}\right)
$$

where $R$ is the universal gas constant, $T$ the absolute temperature, $A$ the active area, $V_{P}$ the permeate volume, $V_{m}$ the molar gas volume at STP conditions, $p_{f}$ the feed pressure, $l$ the membrane thickness, The initial pressure $p_{0}$ and the leak flow rate $(d p / d t)_{0}$ are normally negligible. The last term in Equation (1) corrects for the so-called permeation time lag, $\Theta$, which is inversely proportional to the diffusion coefficient, $D$, of the gas:

$$
\Theta=\frac{l^{2}}{6 D}
$$

The gas solubility coefficient, $S$, was obtained indirectly as the ratio of the permeability to the diffusion coefficient by assuming the solution-diffusion transport mechanism:

$$
S=P / D
$$

Details on the used instrument, designed by Helmholz Zentrum Geesthacht and constructed by EESR (Geesthacht, Germany), can be found elsewhere [39].

\section{Results and Discussion}

\subsection{Polymer Synthesis and Characterisation}

To fully understand the differences in permselectivity arising from the structures of PIM-EA( $\left(\mathrm{Me}_{2}\right)-\mathrm{TB}$ [35] and PIM-Trip $\left(\mathrm{H}_{2}\right)-\mathrm{TB}$, [29] a comprehensive evaluation of the effect of methyl bridgehead substituents was planned. This was provided by preparing TB polymers from ethanoanthracene monomers, with and without methyl groups on the bridgehead (i.e., PIM-EA( $\left(\mathrm{Me}_{2}\right)-\mathrm{TB}$ and PIM-EA $\left(\mathrm{H}_{2}\right)-\mathrm{TB}$, respectively, Figure $\left.1 \mathrm{c}, \mathrm{d}\right)$. Similarly, polymers derived from triptycene monomers with and without bridgehead methyl substituents were prepared (i.e., PIM-Trip $\left(\mathrm{Me}_{2}\right)-\mathrm{TB}$ and $\operatorname{PIM}-\operatorname{Trip}\left(\mathrm{H}_{2}\right)-\mathrm{TB}$, Figure 1a,b). 


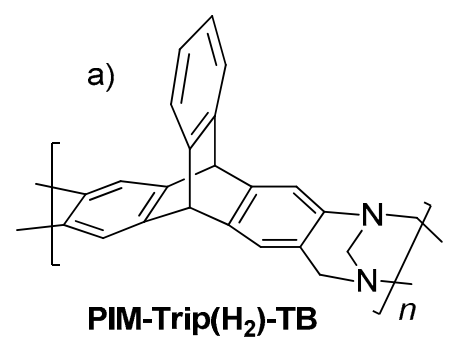

c)

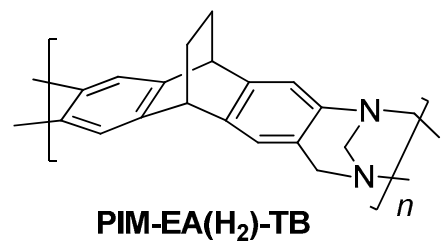

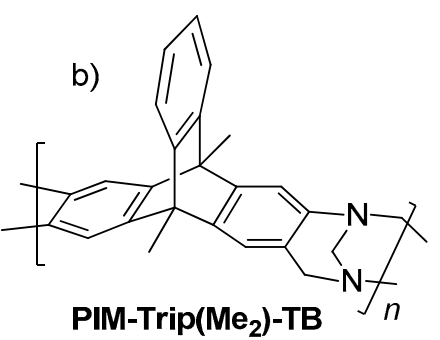

d)

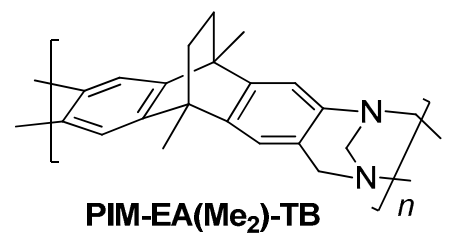

Figure 1. Chemical structure of the TB-PIMs: (a) PIM-Trip $\left(\mathrm{H}_{2}\right)$-TB [29], (b) PIM-Trip(Me $\left.\mathrm{M}_{2}\right)$-TB [This work], (c) PIM-EA( $\left.\mathrm{H}_{2}\right)-\mathrm{TB}[36,40]$ and (d) PIM-EA(Me 2 )-TB [35,41].

The ethanoanthracene $\mathrm{EA}\left(\mathrm{H}_{2}\right)-\mathrm{NH}_{2}$ monomer was prepared following a modified procedure of Cristol et al. [42], starting from the preparation of the cis(trans)dichloro-9,10-ethanoanthracene (Scheme 1). A Diels-Alder reaction was conducted with a cheap commercial mixture of cis/trans 1,2-dichloroethylene and anthracene using microwave irradiation. This was followed by dehalogenation with sodium metal and hydrogenation of the obtained alkene bridge, using the catalytic decomposition of hydrazine monohydrate over Raney-Ni ${ }^{\circledR}$. The hydrocarbon was nitrated with potassium nitrate/TFAA and reduced with hydrazine and Raney-Ni ${ }^{\circledR}$ to obtain the $\mathrm{EA}\left(\mathrm{H}_{2}\right)-\mathrm{NH}_{2}$.

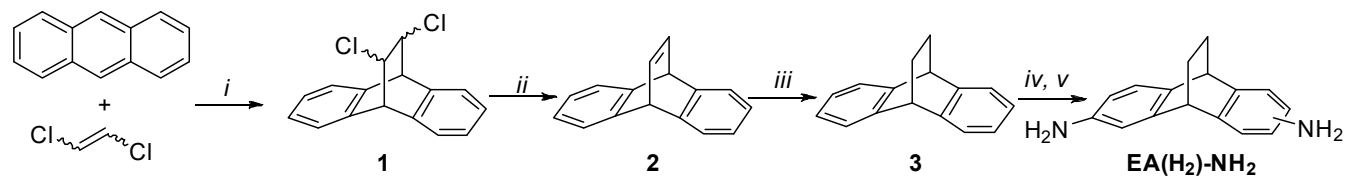

Scheme 1. Synthesis of $\mathrm{EA}\left(\mathrm{H}_{2}\right)-\mathrm{NH}_{2}$. Reagents and conditions: i) $\mathrm{MW}, 215{ }^{\circ} \mathrm{C} ; 5 \mathrm{~h}$; ii) Na, IPA/THF, reflux; iii) Hydrazine, Raney Ni, reflux, 24 h; iv) $\mathrm{KNO}_{3}$, TFAA, $\mathrm{CH}_{3} \mathrm{CN}, 24 \mathrm{~h}$; v) Hydrazine, Raney-Ni ${ }^{\circledR}$, THF, reflux, $16 \mathrm{~h}$.

The synthesis of 9,10-dimethyl-diamino-triptycene [43] Trip $\left(\mathrm{Me}_{2}\right)-\mathrm{NH}_{2}$ monomer was performed as reported in Scheme 2, starting from 9,10-dimethylanthracene (4) and the anthranilic acid, from which we created the diazonium salt that acted as a benzyne precursor. In the same way as $\mathrm{EA}\left(\mathrm{H}_{2}\right)-\mathrm{NH}_{2}$, this was followed by nitration and subsequent reduction, to obtain Trip $\left(\mathrm{Me}_{2}\right)-\mathrm{NH}_{2}$.

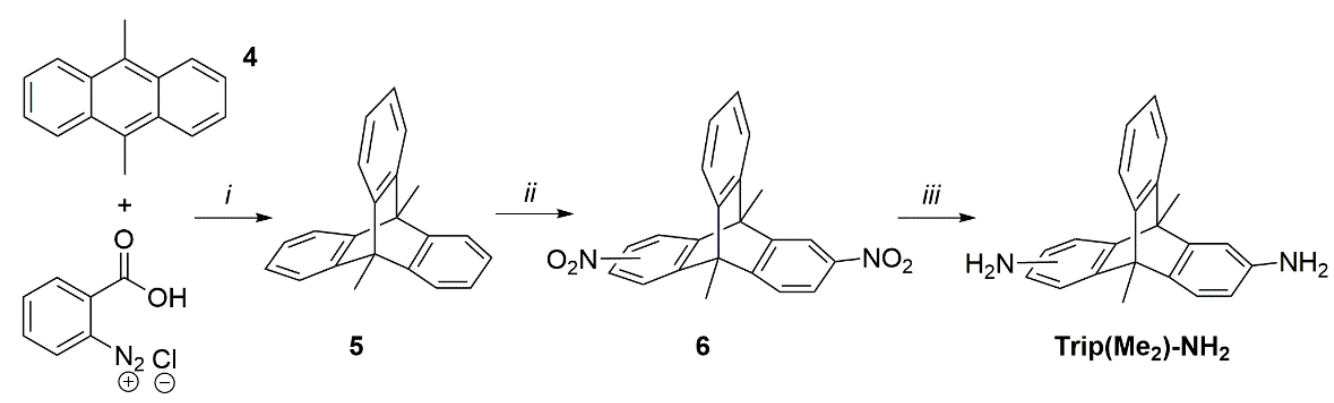

Scheme 2. Synthesis of 2,6(7)-diamino-9,10-dimethyltriptycene Trip $\left(\mathrm{Me}_{2}\right)-\mathrm{NH}_{2}$. Reagents and conditions: i) DCE, $85^{\circ} \mathrm{C}, 4 \mathrm{~h}$; ii) $\mathrm{KNO}_{3}$, TFAA, DCM, $\mathrm{CH}_{3} \mathrm{CN}, 50^{\circ} \mathrm{C}, 48 \mathrm{~h}$; iii). hydrazine monohydrate, Raney-Ni ${ }^{\circledR}$, $\mathrm{THF}, 60^{\circ} \mathrm{C}, \mathrm{N}_{2}, 16 \mathrm{~h}$. 
Trip $\left(\mathrm{Me}_{2}\right)-\mathrm{NH}_{2}$ and EA( $\left.\mathrm{H}_{2}\right)-\mathrm{NH}_{2}$ were reacted with trifluoroacetic acid (TFA) and dimethoxymethane (DMM), under typical TB polymerisation conditions, to form the polymers PIM-Trip $\left(\mathrm{Me}_{2}\right)$-TB and PIM-EA($\left(\mathrm{H}_{2}\right)-\mathrm{TB}$ in high yield and with high molecular mass [32]. The physical characterisation for all the reported TB-PIMs is summarised in Table 1.

Table 1. Summary of the physical properties of TB-PIMs polymers.

\begin{tabular}{|c|c|c|c|c|c|c|}
\hline Polymer & $\begin{array}{c}\text { BET } \\
\text { Surface Area } \\
\left(\mathrm{N}_{2} \text { at } 77 \mathrm{~K}\right) \\
\left(\mathrm{m}^{2} \mathrm{~g}^{-1}\right)\end{array}$ & $\begin{array}{c}\text { Total Pore Volume at } \\
\left(\mathrm{P} / \mathrm{P}_{0}\right)=0.9814 \\
\left(\mathrm{~cm}^{3} \mathrm{~g}^{-1}\right)\end{array}$ & $\begin{array}{l}\mathrm{Mw} \times 10^{3} \\
\left(\mathrm{~g} \mathrm{~mol}^{-1}\right)\end{array}$ & PDI & $\begin{array}{c}\mathrm{CO}_{2} \text { Uptake } \\
(273 \mathrm{~K}, 1 \text { bar }) \\
\mathrm{cc}^{-1} \\
\left(\mathrm{mmol} \mathrm{g}^{-1}\right)\end{array}$ & Ref. \\
\hline PIM-EA($\left(\mathrm{Me}_{2}\right)-\mathrm{TB}$ & 1028 & 0.75 & 156 & 3.8 & $\begin{array}{c}79.3 \\
(3.54)\end{array}$ & [35] \\
\hline PIM-Trip $\left(\mathrm{Me}_{2}\right)-\mathrm{TB}$ & 926 & 0.65 & 118 & 2.7 & $\begin{array}{c}87.0 \\
(3.88)\end{array}$ & This work \\
\hline PIM-EA( $\left.\mathrm{H}_{2}\right)-\mathrm{TB}$ & 845 & 0.62 & 62 & 2.3 & $\begin{array}{c}71.8 \\
(3.20)\end{array}$ & {$[36,40]$} \\
\hline PIM-Trip $\left(\mathrm{H}_{2}\right)-\mathrm{TB}$ & 899 & 0.55 & 50 & 2.4 & $\begin{array}{c}90.4 \\
(4.03)\end{array}$ & [29] \\
\hline
\end{tabular}

The measurement of the apparent BET surface area reveals that the absence of methyl substituents on the bridgehead for PIM-EA $\left(\mathrm{H}_{2}\right)-\mathrm{TB}$ lead to a less microporous material than the related "methyl-containing" polymer PIM-EA(Me $\left.\mathrm{Me}_{2}\right)$-TB [35]. This is most likely due to the better packing of the polymeric chains in the solid state. This confirms the hypothesis made in our 2014 study [29], where we attributed the slightly reduced surface area to the lack of methyl substituents that act as "spacer" between polymeric chains. However, in the case of PIM-Trip( $\left(\mathrm{Me}_{2}\right)$-TB the physical characterisation displayed only a marginally higher BET surface area than its related "methyl-lacking" polymer PIM-Trip $\left(\mathrm{H}_{2}\right)$-TB [29].

For all the reported polymers, the $\mathrm{CO}_{2}$ sorption measurements at $273 \mathrm{~K}$ (Table 1 and Figure $2 \mathrm{~b}$ ) demonstrated a high total $\mathrm{CO}_{2}$ uptake of the TB-PIMs, while the relatively steep initial slope of the sorption curve indicates a high affinity compared to other PIMs. Indeed, gravimetric sorption measurements at $298 \mathrm{~K}$ have shown that PIM-EA( $\left.\mathrm{H}_{2}\right)-\mathrm{TB}$ and PIM-Trip $\left(\mathrm{H}_{2}\right)-\mathrm{TB}$ have the highest $\mathrm{CO}_{2}$ affinity for any PIM or high free volume polymer, with the exception of Amine-PIM-1 [44]. We attribute this to the basic tertiary amines of the $\mathrm{TB}$ core and the ultramicroporous structures generated by the polymers. Looking at the results in detail, the $\mathrm{CO}_{2}$ adsorption proved higher for the triptycene-based polymers, with similar or lower total pore volume than the ethanoanthracene-based polymers. This suggests that the triptycene-based polymers undergo stronger dilation upon absorption of $\mathrm{CO}_{2}$, explaining the decrease in selectivity with increasing pressure as reported by Genduso et al. [37]. This is also the reason why the presence of ultramicropores leads to a favourable combination of permeability and excellent selectivity for gases with low affinity and large difference in size, such as $\mathrm{O}_{2} / \mathrm{N}_{2}$ and $\mathrm{H}_{2} / \mathrm{N}_{2}$ but not necessarily for gas pairs involving $\mathrm{CO}_{2}$, which may remain 'trapped' if the affinity for the polymer chain segments surrounding the pore are too high (see discussion below).

A qualitative evaluation of the pore size distribution (PSD), obtained by $\mathrm{CO}_{2}$ adsorption measurement at $273 \mathrm{~K}$ and evaluated with NLDFT and Horvath-Kawazoe (H-K) models (Figure 3 and inset), showed the typical bimodal distribution of PIMs, with a set of very narrow pores centred at $\sim 0.4 \mathrm{~nm}$ and a second set of slightly larger pores centred at $\sim 0.6 \mathrm{~nm}$. The NLDFT analysis shows a broader distribution of the ultramicropores in both Trip-based polymers than in both EA-based polymers, with the peak height in the differential pore volume changing in the order PIM-Trip $\left(\mathrm{Me}_{2}\right)-\mathrm{TB}$ $>$ PIM-Trip $\left(\mathrm{H}_{2}\right)-\mathrm{TB}$, and PIM-EA( $\left(\mathrm{Me}_{2}\right)-\mathrm{TB}>\mathrm{PIM}-\mathrm{EA}\left(\mathrm{H}_{2}\right)$-TB. Instead, the H-K model shows a slightly higher total ultramicropore volume in PIM-Trip $\left(\mathrm{H}_{2}\right)-\mathrm{TB}$ than in PIM-Trip $\left(\mathrm{Me}_{2}\right)-\mathrm{TB}$, so quantitative interpretation of these results should be conducted with caution. 

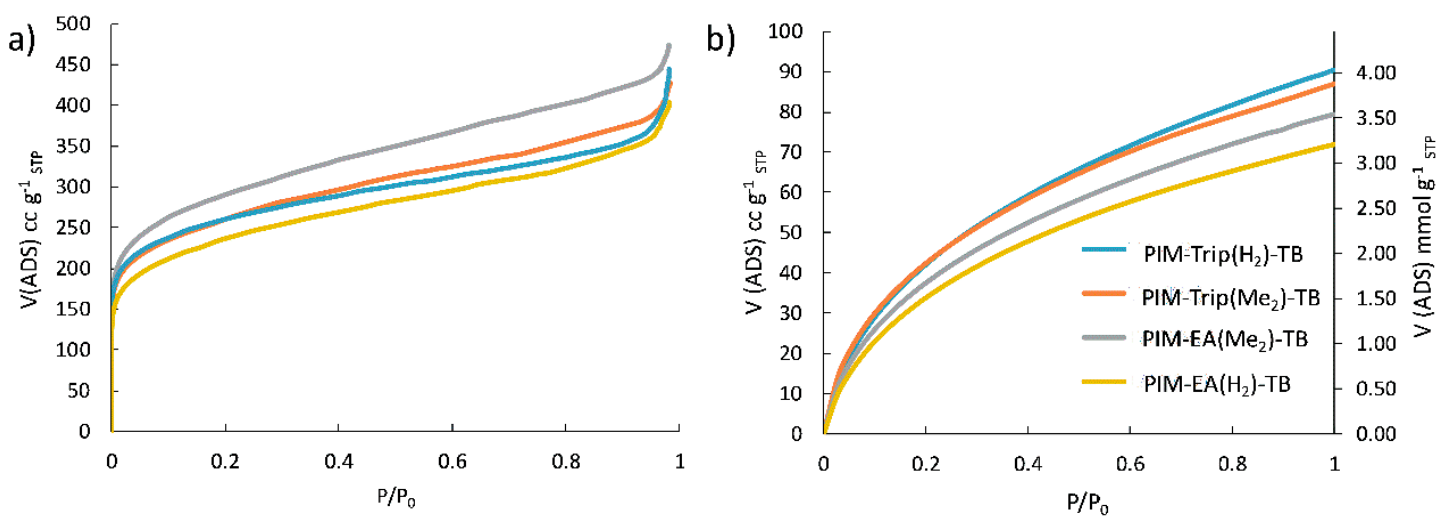

Figure 2. (a) $\mathrm{N}_{2}$ adsorption isotherms measured at $77 \mathrm{~K}$ (desorption curves are not shown for clarity); (b) $\mathrm{CO}_{2}$ uptake measured at $273 \mathrm{~K}$.

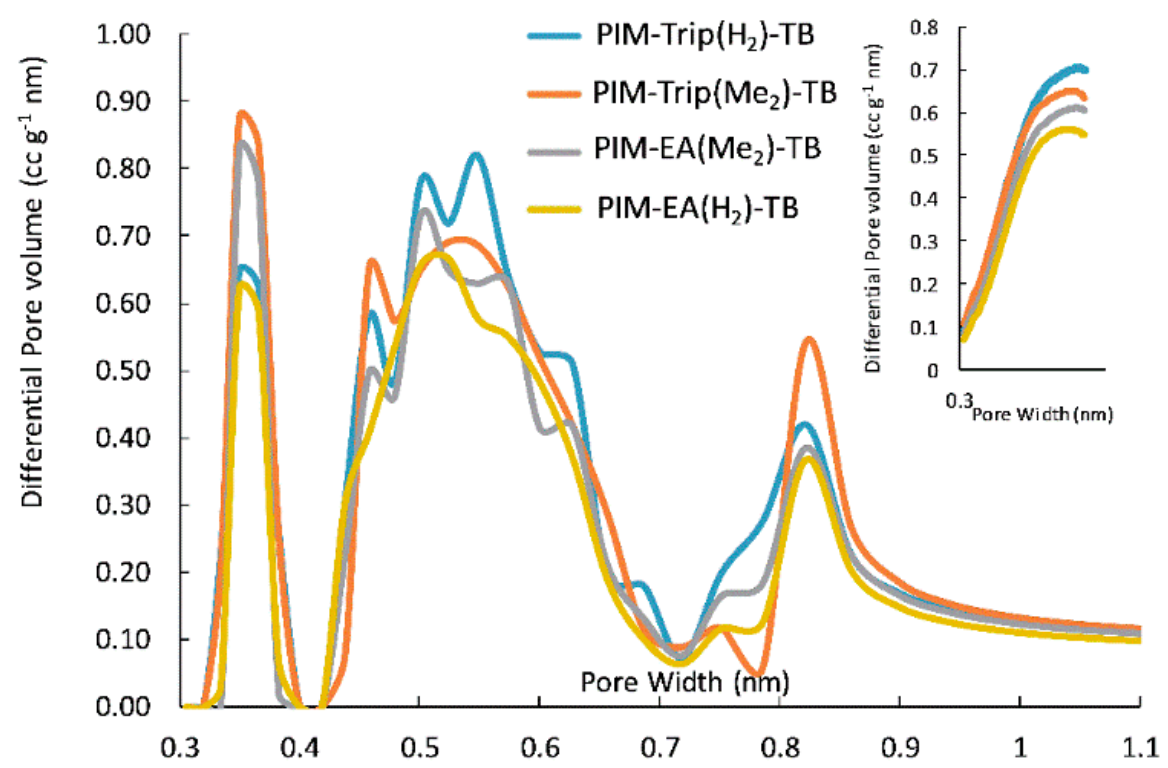

Figure 3. NLDFT and $\mathrm{H}-\mathrm{K}$ (inset) model PSD measured from $\mathrm{CO}_{2}$ at $273 \mathrm{~K}$.

\subsection{Membrane Preparation and Gas Permeability Measurements}

The polymers all showed complete solubility in chloroform, allowing the preparation of robust self-standing films suitable for gas permeation measurements. Despite their higher BET surface areas, PIM-EA(Me $\mathrm{Me}_{2}$-TB and PIM-Trip $\left(\mathrm{Me}_{2}\right)$-TB showed similar or lower gas permeability than their "methyl-less" counterparts (Table 2 and Figure 4). For $\mathrm{CO}_{2}$, the permeability of PIM-Trip $\left(\mathrm{H}_{2}\right)$-TB is around three times that of PIM-Trip $\left(\mathrm{Me}_{2}\right)$-TB. This is consistent with our previous suggestion that PIMs without methyl substituents on the bridgehead retain a higher amount of accessible free volume [29]. In contrast, PIM-EA( $\left.\mathrm{Me}_{2}\right)$-TB has greater permeability than PIM-EA( $\left.\mathrm{H}_{2}\right)-\mathrm{TB}$. 

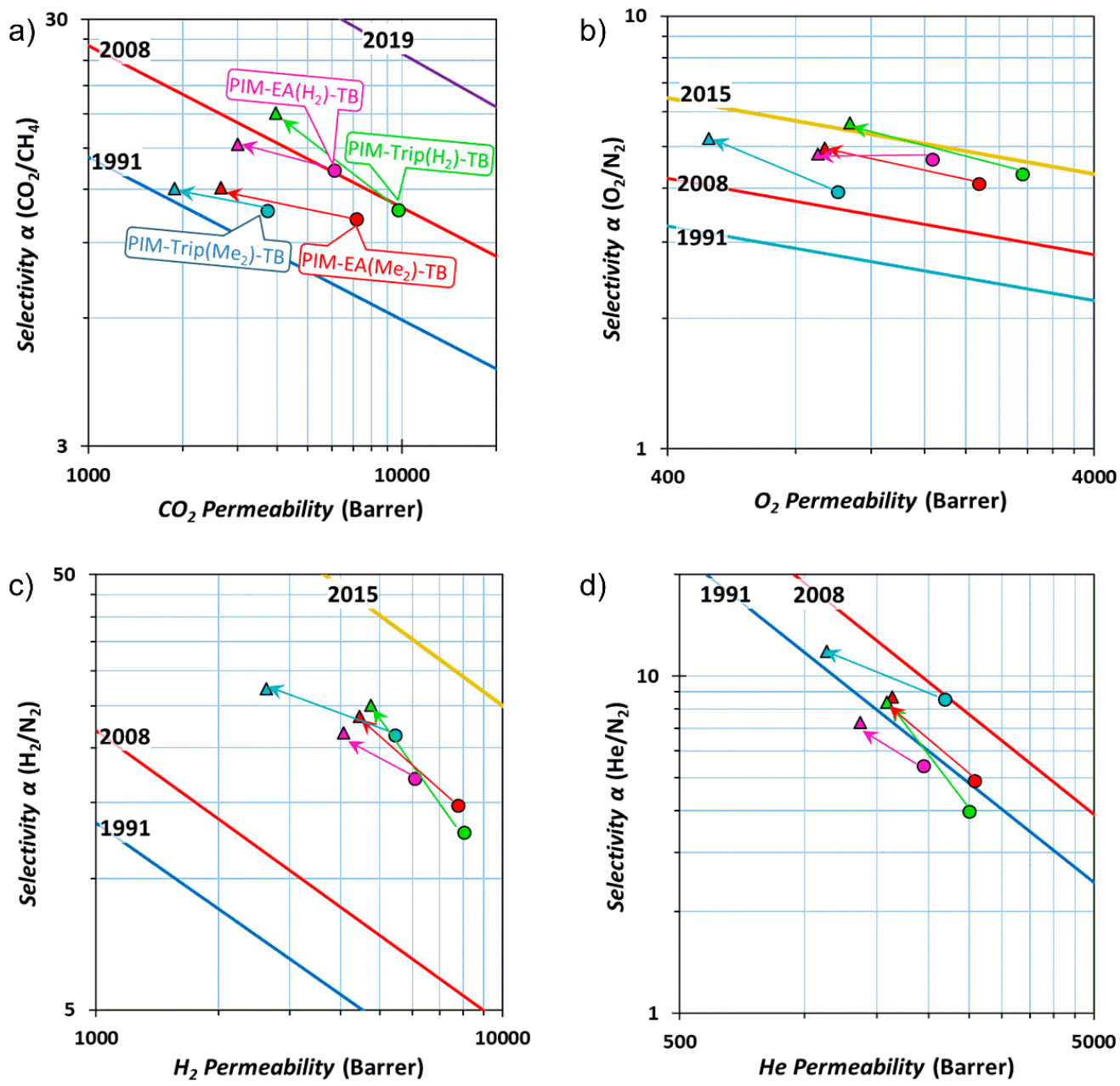

Figure 4. Robeson's plots of the four TB-PIMs. Measurements at $25^{\circ} \mathrm{C}$ and 1 bar feed pressure. Data are reported for methanol treated (circles) and aged (triangles) samples. Arrows indicates the change in permselectivities for aged samples of PIM-Trip $\left(\mathrm{H}_{2}\right)$-TB (green, 102 days), PIM-Trip $\left(\mathrm{Me}_{2}\right)$-TB (blue, 407 days), PIM-EA( $\left.\mathrm{H}_{2}\right)$-TB (violet, 119 days) and PIM-EA( $\left(\mathrm{Me}_{2}\right)$-TB (red, 106 days). Continuous lines represent the different upper bounds: 1991 [21], 2008 [23], 2015 [24], and 2019 [25].

In addition, the reported polymers present different permeation orders for the investigated gases, depending on the bridgehead substituents. PIM-Trip $\left(\mathrm{Me}_{2}\right)$-TB and, at a lower extent, PIM-EA(Me $\left.\mathrm{M}_{2}\right)-\mathrm{TB}$, show a larger permeability for $\mathrm{H}_{2}$ than $\mathrm{CO}_{2}$. Instead, the "methyl-less" TB-PIMs display an 'inverse selectivity' (i.e., $\mathrm{CO}_{2}>\mathrm{H}_{2}$ ). This is particularly evident for the PIM-Trip $\left(\mathrm{H}_{2}\right)$-TB, consistent with the $\mathrm{CO}_{2}$ uptake data at $273 \mathrm{~K}$ (Table 1). Only for $\mathrm{H}_{2}$ does PIM-EA(Me $\mathrm{M}_{2}$-TB prove slightly more permeable than PIM-EA($\left(\mathrm{H}_{2}\right)$-TB (Figure 4 and Table 2), but still far from the values of PIM-Trip $\left(\mathrm{H}_{2}\right)$-TB. This resulted in overall better performance for the two $\mathrm{H}_{2}$-bridgehead TB-PIMs for important gas pairs, surpassing the 2008 upper bound and approaching the 2015 upper bound for $\mathrm{O}_{2} / \mathrm{N}_{2}$, and $\mathrm{H}_{2} / \mathrm{N}_{2}$. As shown in Figure 4, both PIM-Trip $\left(\mathrm{H}_{2}\right)$-TB and PIM-EA( $\left(\mathrm{H}_{2}\right)$-TB perform better for the important $\mathrm{O}_{2} / \mathrm{N}_{2}$ gas pair than the related Me-containing polymers, implying better molecular sieving, since their separation relies predominantly on diffusivity selectivity.

Rapid physical ageing is a characteristic feature of PIMs and other superglassy polymers, which leads to a decrease in permeability, coupled with a commensurate increase of selectivity, often following the typical Robeson trade-off. In the case of several TB-PIMs, we reported previously that the increase of selectivity is often greater than the related decrease of permeability, which places their data in a more favourable area of the Robeson plots $[29,33,34]$. This trend is also confirmed for the PIMs in the current study and is especially evident when evaluating the data of the $\mathrm{H}_{2}$-bridgehead TB-PIMs. In fact, aged 
samples of PIM-EA($\left(\mathrm{H}_{2}\right)$-TB and PIM-Trip $\left(\mathrm{H}_{2}\right)$-TB show, once more, better performance than the related Me-bridgehead samples. In particular, despite the expected loss of permeability, physical ageing helps PIM-Trip $\left(\mathrm{H}_{2}\right)$-TB to surpass the 2008 upper bound for $\mathrm{CO}_{2} / \mathrm{CH}_{4}$. A similar trend is also observed for the $\mathrm{H}_{2} / \mathrm{CH}_{4}$ gas pair where, again, ageing improves the overall performance of the $\mathrm{H}_{2}$-bridgehead polymers, whereas PIM-EA( $\left(\mathrm{Me}_{2}\right)$-TB and PIM-Trip $\left(\mathrm{Me}_{2}\right)$-TB show the opposite behaviour.

For the freshly $\mathrm{MeOH}$ treated membranes, the diffusion coefficients for most gases decrease in the order PIM-Trip $\left(\mathrm{H}_{2}\right)$-TB $>$ PIM-EA $\left(\mathrm{Me}_{2}\right)$-TB $>$ PIM-EA $\left(\mathrm{H}_{2}\right)$-TB $>$ PIM-Trip $\left(\mathrm{Me}_{2}\right)$-TB (Figure 5a). The size selectivity, expressed by the slope of the best fit for the data of oxygen, carbon dioxide, nitrogen and methane [45], increases in the same order. With exception of $\mathrm{CO}_{2}$ and $\mathrm{N}_{2}$, which are inverted in all fresh samples but PIM-EA( $\left.\mathrm{H}_{2}\right)-\mathrm{TB}$, the diffusion coefficient decreases with increasing effective molecular diameter as defined by Teplyakov and Meares [46]. After ageing, the diffusion coefficient decreases with the gas diameter more markedly (Figure $5 b$ ), evidencing a stronger size selectivity of the polymers [30]. Interestingly, PIM-Trip $\left(\mathrm{H}_{2}\right)$-TB maintains a relatively high diffusion coefficient for smaller gas molecules upon ageing, but it becomes the most size selective, whereas PIM-Trip $\left(\mathrm{Me}_{2}\right)-\mathrm{TB}$ shows exactly the opposite trend, with the lowest diffusion coefficient and the lowest size selectivity.

Table 2. Gas permeabilities $P_{x}$, diffusivity $D_{x}$, solubility coefficient $S_{x}$ for methanol treated films of TB-PIMs (data from aged films in parentheses and square brackets). Measurements at $25^{\circ} \mathrm{C}$ and 1 bar feed pressure.

\begin{tabular}{|c|c|c|c|c|c|c|c|}
\hline \multirow{2}{*}{ PIM } & \multirow{2}{*}{ Transport Parameters } & \multicolumn{6}{|c|}{ Gas Type } \\
\hline & & $\mathbf{N}_{2}$ & $\mathrm{O}_{2}$ & $\mathrm{CO}_{2}$ & $\mathrm{CH}_{4}$ & $\mathrm{H}_{2}$ & $\mathrm{He}$ \\
\hline \multirow[t]{3}{*}{$\operatorname{Trip}\left(\mathrm{Me}_{2}\right)-\mathrm{TB}$} & $\begin{array}{c}P_{x}[\text { Barrer }] \\
(\text { aged })^{\text {a) }}\end{array}$ & $\begin{array}{l}255 \\
(96)\end{array}$ & $\begin{array}{l}1002 \\
(500)\end{array}$ & $\begin{array}{c}3718 \\
(1880)\end{array}$ & $\begin{array}{c}347 \\
(156)\end{array}$ & $\begin{array}{c}5446 \\
(2625)\end{array}$ & $\begin{array}{c}2178 \\
(1134)\end{array}$ \\
\hline & $\begin{array}{c}D_{x}\left[10^{-12} \mathrm{~m}^{2} \mathrm{~s}^{-1}\right] \\
(\text { aged })^{\text {a) }}\end{array}$ & $\begin{array}{c}25 \\
(12.7)\end{array}$ & $\begin{array}{c}106 \\
(63.6)\end{array}$ & $\begin{array}{c}24 \\
(17.8)\end{array}$ & $\begin{array}{c}8 \\
(4.8)\end{array}$ & $\begin{array}{c}4393 \\
(2487)\end{array}$ & $\begin{array}{c}7580 \\
(4424)\end{array}$ \\
\hline & $\begin{array}{c}S_{x}\left[\mathrm{~cm}^{3} \mathrm{~cm}^{-3} \text { bar }^{-1}\right] \\
(\text { aged })^{\text {a) }}\end{array}$ & $\begin{array}{c}7.53 \\
(5.69)\end{array}$ & $\begin{array}{c}7.12 \\
(5.90)\end{array}$ & $\begin{array}{l}117 \\
(79)\end{array}$ & $\begin{array}{c}34.2 \\
(24.3)\end{array}$ & $\begin{array}{c}0.93 \\
(0.79)\end{array}$ & $\begin{array}{c}0.22 \\
(0.19)\end{array}$ \\
\hline \multirow[t]{3}{*}{$\mathrm{EA}\left(\mathrm{Me}_{2}\right)-\mathrm{TB}[35]$} & $\begin{array}{c}P_{x}[\text { Barrer }] \\
\left.(\text { aged })^{b}\right)\end{array}$ & $\begin{array}{c}525 \\
(188)\end{array}$ & $\begin{array}{l}2150 \\
(933)\end{array}$ & $\begin{array}{c}7140 \\
(2644)\end{array}$ & $\begin{array}{c}699 \\
(219)\end{array}$ & $\begin{array}{c}7760 \\
(4442)\end{array}$ & $\begin{array}{c}2570 \\
(1630)\end{array}$ \\
\hline & $\begin{array}{c}D_{x}\left[10^{-12} \mathrm{~m}^{2} \mathrm{~s}^{-1}\right] \\
(\text { aged })^{\mathrm{b})}\end{array}$ & $\begin{array}{c}99.5 \\
(22.9)\end{array}$ & $\begin{array}{c}318 \\
(104)\end{array}$ & $\begin{array}{c}87 \\
(35.2)\end{array}$ & $\begin{array}{c}36 \\
(6.9)\end{array}$ & $\begin{array}{l}>7000 \\
(4000)\end{array}$ & $\begin{array}{l}>10000 \\
(7700)\end{array}$ \\
\hline & $\begin{array}{c}S_{x}\left[\mathrm{~cm}^{3} \mathrm{~cm}^{-3} \mathrm{bar}^{-1}\right] \\
(\text { aged })\end{array}$ & $\begin{array}{c}3.96 \\
(6.16)\end{array}$ & $\begin{array}{c}5.07 \\
(6.73)\end{array}$ & $\begin{array}{c}61.5 \\
(56.3)\end{array}$ & $\begin{array}{l}14.56 \\
23.81\end{array}$ & $\begin{array}{c}0.83 \\
(0.83)\end{array}$ & $\begin{array}{c}0.19 \\
(0.16)\end{array}$ \\
\hline \multirow[t]{3}{*}{$\mathrm{EA}\left(\mathrm{H}_{2}\right)-\mathrm{TB}$} & $\begin{array}{c}P_{x}[\text { Barrer }] \\
\left.(\text { aged })^{c}\right)\end{array}$ & $\begin{array}{c}358 \\
(188)\end{array}$ & $\begin{array}{l}1673 \\
(902)\end{array}$ & $\begin{array}{c}6097 \\
(2999)\end{array}$ & $\begin{array}{c}458 \\
(196)\end{array}$ & $\begin{array}{c}6088 \\
(4066)\end{array}$ & $\begin{array}{c}1938 \\
(1367)\end{array}$ \\
\hline & $\begin{array}{c}D_{x}\left[10^{-12} \mathrm{~m}^{2} \mathrm{~s}^{-1}\right] \\
(\text { aged })^{\mathrm{c})}\end{array}$ & $\begin{array}{c}47.6 \\
(26.5)\end{array}$ & $\begin{array}{c}216 \\
(121)\end{array}$ & $\begin{array}{c}66.4 \\
(29.7)\end{array}$ & $\begin{array}{l}15.1 \\
(5.5)\end{array}$ & $\begin{array}{c}5635 \\
(4074)\end{array}$ & $\begin{array}{c}7822 \\
(6269)\end{array}$ \\
\hline & $\begin{array}{c}S_{x}\left[\mathrm{~cm}^{3} \mathrm{~cm}^{-3} \mathrm{bar}^{-1}\right] \\
(\text { aged })^{\mathrm{c})}\end{array}$ & $\begin{array}{c}5.64 \\
(5.32)\end{array}$ & $\begin{array}{c}5.81 \\
(5.60)\end{array}$ & $\begin{array}{c}68.87 \\
(75.74)\end{array}$ & $\begin{array}{c}22.75 \\
(26.73)\end{array}$ & $\begin{array}{c}0.81 \\
(0.75)\end{array}$ & $\begin{array}{c}0.19 \\
(0.16)\end{array}$ \\
\hline \multirow[t]{3}{*}{$\operatorname{Trip}\left(\mathrm{H}_{2}\right)-\mathrm{TB}[29]$} & $\begin{array}{c}P_{x}[\text { Barrer }] \\
(\text { aged }) \mathrm{d})\end{array}$ & $\begin{array}{c}629 \\
(189)\end{array}$ & $\begin{array}{c}2718 \\
(1073)\end{array}$ & $\begin{array}{c}9709 \\
(3951)\end{array}$ & $\begin{array}{c}905 \\
(218)\end{array}$ & $\begin{array}{c}8039 \\
(4740)\end{array}$ & $\begin{array}{c}2500 \\
(1585)\end{array}$ \\
\hline & $\begin{array}{c}D_{x}\left[10^{-12} \mathrm{~m}^{2} \mathrm{~s}^{-1}\right] \\
(\text { aged }) \mathrm{d})\end{array}$ & $\begin{array}{c}135 \\
(28.5)\end{array}$ & $\begin{array}{c}462 \\
(148)\end{array}$ & $\begin{array}{c}111 \\
(34.6)\end{array}$ & $\begin{array}{l}48.9 \\
(7.5)\end{array}$ & $\begin{array}{c}7800 \\
(4920)\end{array}$ & $\begin{array}{c}>10000 \\
(7738)\end{array}$ \\
\hline & $\begin{array}{c}S_{x}\left[\mathrm{~cm}^{3} \mathrm{~cm}^{-3} \mathrm{bar}^{-1}\right] \\
(\text { aged) })\end{array}$ & $\begin{array}{c}3.49 \\
(4.97)\end{array}$ & $\begin{array}{c}4.41 \\
(5.43)\end{array}$ & $\begin{array}{l}65.61 \\
(85.6)\end{array}$ & $\begin{array}{c}13.88 \\
(21.75)\end{array}$ & $\begin{array}{c}0.77 \\
(0.72)\end{array}$ & $\begin{array}{c}0.18 \\
(0.15)\end{array}$ \\
\hline
\end{tabular}

a) Age 407 days; $^{\text {b) }}$ Age 106 days; $^{\text {c) }}$ Age 119 days; ${ }^{\text {d) }}$ Age 102 days. 

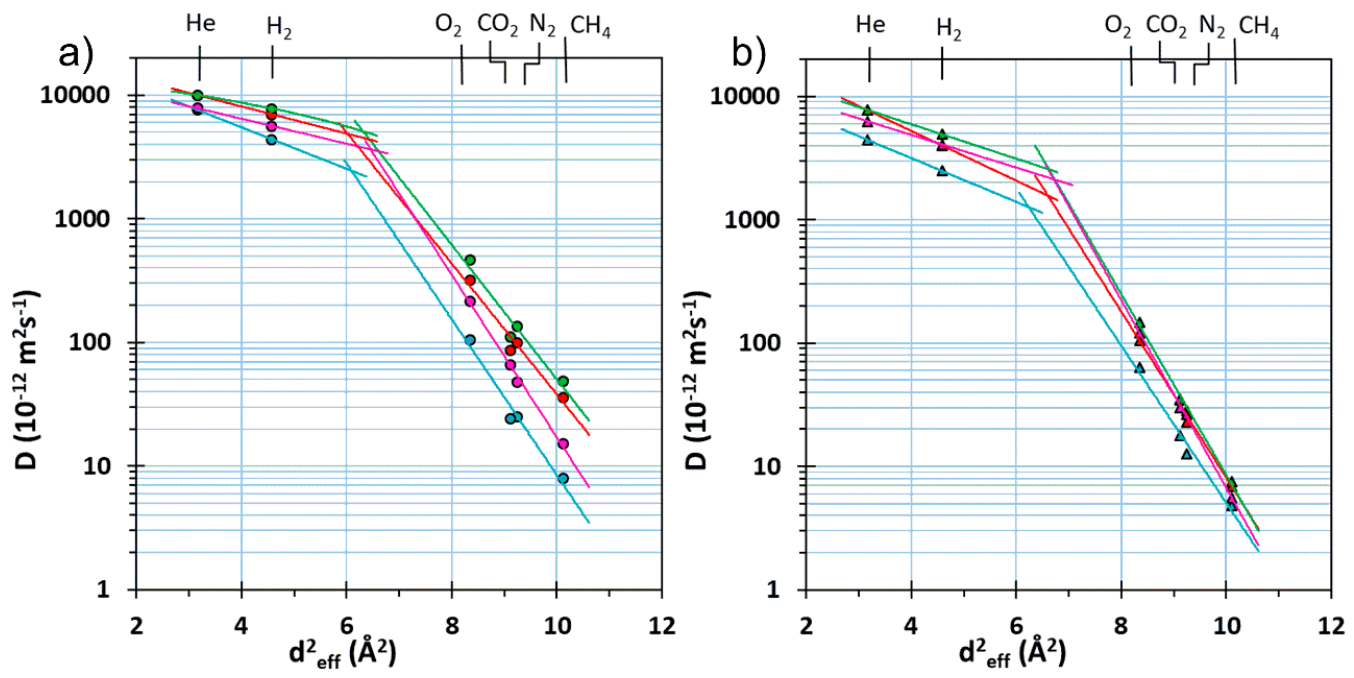

Figure 5. Correlation of the diffusion coefficient and effective gas diameter [46] for the MeOH-treated PIM-Trip $\left(\mathrm{H}_{2}\right)$-TB (green), PIM-Trip( $\left.\mathrm{Me}_{2}\right)$-TB (blue), PIM-EA( $\left.\mathrm{H}_{2}\right)$-TB (violet) and PIM-EA( $\left.\mathrm{Me}_{2}\right)$-TB (red) membranes (a), and the same samples after ageing for 102, 407, 119 and 106 days, respectively (b). Lines represent the best fit of the data for helium and hydrogen, and for oxygen, carbon dioxide, nitrogen and methane, respectively. Measurements at $25^{\circ} \mathrm{C}$ and 1 bar feed pressure.

To summarize, the present manuscript confirms the possibility to tailor the transport properties of PIMs by the targeted use of bulky or contorted groups in the backbone, but it also shows that one of their difficulties is that even their basic properties, like the BET surface area or the total pore volume, depend on a multitude of factors and must always be used in combination with other properties to fully understand the correlation with the transport properties. In our case, all polymers have fundamentally the same backbone, and the lateral methyl groups may serve as spacers that create free volume, but if space is created by other groups, they may also fill that space. On the other hand, the triptycene groups are also expected to serve as spacers between the chains, but if they occasionally meet in an antiparallel alignment, their $\pi-\pi$ stacking reduces the surface area with respect to individual triptycene groups. Therefore, high BET surface area and high pore volume are correlated but not necessarily in a straightforward way, because the BET area depends strongly on the pore (or better: free volume element) size distribution and interconnectivity rather than just on the total pore volume. In turn, permeability depends on both the total free volume and the free volume element size distribution, while selectivity depends more on the bottlenecks between the free volume elements [45].

\section{Conclusions}

We provide a systematic evaluation of the effect on the physical properties of methyl bridgehead substituents on the ethanoanthracene or triptycene unit for a series of TB-PIMs. Comparison of the "methyl-less" PIM-EA( $\left.\mathrm{H}_{2}\right)$-TB and PIM-Trip $\left(\mathrm{H}_{2}\right)$-TB with their methyl-substituted equivalents suggests reduced overall porosity but enhanced interconnection between pores, making accessible more internal free volume. This was evaluated by both surface area and gas permeability measurements. In fact, despite the higher apparent BET surface area of PIM-Trip $\left(\mathrm{Me}_{2}\right)$-TB and PIM-EA(Me $\left(\mathrm{Me}_{2}\right)-\mathrm{TB}$, the overall permselectivity performance of the $\mathrm{H}_{2}$-bridgehead TB-PIMs proved superior for all measured gas pairs, with better molecular sieving. Ageing increases the size selectivity of the membranes, and this effect is strongest for PIM-Trip $\left(\mathrm{H}_{2}\right)$-TB and weakest for PIM-Trip $\left(\mathrm{Me}_{2}\right)$-TB.

In conclusion, the present work shows how complex the correlations can be between physical parameters such as the total pore volume and the BET surface area, on the one hand, and gas permeability and the selectivity on the other hand. All are dependent on the total free volume or, more correctly, amount of free volume elements (FVE), but gas permeability and selectivity are also strongly dependent on pore-size distribution and pore interconnectivity (i.e., the diameter of bottlenecks 
between the FVEs). These, in turn, depend on the type, orientation and final packing of the bulky groups in the polymer backbone, dilation phenomena, etc. This suggests the future use of molecular simulations of three-dimensional polymer chain packing and X-ray diffraction measurements in order to further increase our understanding of the properties of these PIMs.

Supplementary Materials: The following are available online at http://www.mdpi.com/2077-0375/10/4/62/s1. Figure S1: Gel permeation chromatography trace for PIM-Trip( $\left.\mathrm{Me}_{2}\right)$-TB.

Author Contributions: The draft manuscript was written through major contributions of M.C., J.C.J., A.F. and N.B.M with help of all other authors. Contributions to the experimental work are: R.M.-E. and I.R. synthesized most of the polymers, with help and supervision of M.C. and N.B.M.; A.F. elaborated the correlations and prepared most of the graphs of the gas transport properties, determined by P.B. and G.C. with help and under direct supervision of J.C.J.; The final version of the manuscript was revised and edited by M.C., J.C.J. and N.B.M. All authors have read and agreed to the published version of the manuscript.

Funding: The work leading to these results has received funding from the European Union's Seventh Framework Program (FP7/2007-2013) under grant agreement $\mathrm{n}^{\circ}$ 608490, project $\mathrm{M}^{4} \mathrm{CO}_{2}$.

Conflicts of Interest: The authors declare no conflict of interest.

\section{References}

1. Buonomenna, M.G. Membrane processes for a sustainable industrial growth. RSC Adv. 2013, 3, 5694-5740. [CrossRef]

2. Zhang, H.; Shen, P.K. Recent Development of Polymer Electrolyte Membranes for Fuel Cells. Chem. Rev. 2012, 112, 2780-2832. [CrossRef] [PubMed]

3. Chaoui, N.; Trunk, M.; Dawson, R.; Schmidt, J.; Thomas, A. Trends and challenges for microporous polymers. Chem. Soc. Rev. 2017, 46, 3302-3321. [CrossRef] [PubMed]

4. Koros, W.J.; Zhang, C. Materials for next-generation molecularly selective synthetic membranes. Nat. Mater. 2017, 16, 289-297. [CrossRef]

5. Adewole, J.K.; Ahmad, A.L.; Ismail, S.; Leo, C.P. Current challenges in membrane separation of $\mathrm{CO}_{2}$ from natural gas: A review. Int. J. Greenh. Gas Control 2013, 17, 46-65. [CrossRef]

6. Baker, R.W.; Lokhandwala, K. Natural Gas Processing with Membranes: An Overview. Ind. Eng. Chem. Res. 2008, 47, 2109-2121. [CrossRef]

7. Bernardo, P.; Drioli, E.; Golemme, G. Membrane Gas Separation: A Review/State of the Art. Ind. Eng. Chem. Res. 2009, 48, 4638-4663. [CrossRef]

8. Sanders, D.F.; Smith, Z.P.; Guo, R.; Robeson, L.M.; McGrath, J.E.; Paul, D.R.; Freeman, B.D. Energy-efficient polymeric gas separation membranes for a sustainable future: A review. Polymer 2013, 54, 4729-4761. [CrossRef]

9. Yampolskii, Y. Polymeric Gas Separation Membranes. Macromolecules 2012, 45, 3298-3311. [CrossRef]

10. Shao, L.; Low, B.T.; Chung, T.-S.; Greenberg, A.R. Polymeric membranes for the hydrogen economy: Contemporary approaches and prospects for the future. J. Membr. Sci. 2009, 327, 18-31. [CrossRef]

11. Ockwig, N.W.; Nenoff, T.M. Membranes for Hydrogen Separation. Chem. Rev. 2007, 107, 4078-4110. [CrossRef] [PubMed]

12. Bandyopadhyay, S.; Anil, A.G.; James, A.; Patra, A. Multifunctional Porous Organic Polymers: Tuning of Porosity, $\mathrm{CO}_{2}$, and $\mathrm{H}_{2}$ Storage and Visible-Light-Driven Photocatalysis. ACS Appl. Mater. Interfaces 2016, 8 , 27669-27678. [CrossRef] [PubMed]

13. Du, N.; Park, H.B.; Dal-Cin, M.M.; Guiver, M.D. Advances in high permeability polymeric membrane materials for $\mathrm{CO}_{2}$ separations. Energy Environ. Sci. 2012, 5, 7306-7322. [CrossRef]

14. Merkel, T.C.; Zhou, M.; Baker, R.W. Carbon dioxide capture with membranes at an IGCC power plant. J. Membr. Sci. 2012, 389, 441-450. [CrossRef]

15. Lau, C.H.; Nguyen, P.T.; Hill, M.R.; Thornton, A.W.; Konstas, K.; Doherty, C.M.; Mulder, R.J.; Bourgeois, L.; Liu, A.C.Y.; Sprouster, D.J.; et al. Ending Aging in Super Glassy Polymer Membranes. Angew. Chem. Int. Ed. 2014, 53, 5322-5326. [CrossRef]

16. Wang, J.; Wang, S.; Xin, Q.; $\mathrm{Li}$, Y. Perspectives on water-facilitated $\mathrm{CO}_{2}$ capture materials. J. Mater. Chem. A 2017, 5, 6794-6816. [CrossRef] 
17. Roussanaly, S.; Anantharaman, R. Cost-optimal $\mathrm{CO}_{2}$ capture ratio for membrane-based capture from different $\mathrm{CO}_{2}$ sources. Chem. Eng. J. 2017, 327, 618-628. [CrossRef]

18. Sabetghadam, A.; Liu, X.; Orsi, A.F.; Lozinska, M.M.; Johnson, T.; Jansen, K.M.; Wright, P.A.; Carta, M.; McKeown, N.B.; Kapteijn, F. Towards High Performance Metal-Organic Framework-Microporous Polymer Mixed Matrix Membranes: Addressing Compatibility and Limiting Aging by Polymer Doping. Chem. A Eur. J. 2018, 24, 12796-12800. [CrossRef]

19. Esposito, E.; Dellamuzia, L.; Moretti, U.; Fuoco, A.; Giorno, L.; Jansen, J.C. Simultaneous production of biomethane and food grade $\mathrm{CO}_{2}$ from biogas: An industrial case study. Energy Environ. Sci. 2019, 12, 281-289. [CrossRef]

20. Budd, P.M.; McKeown, N.B. Highly permeable polymers for gas separation membranes. Polym. Chem. 2010, 1, 63-68. [CrossRef]

21. Robeson, L.M. Correlation of separation factor versus permeability for polymeric membranes. J. Membr. Sci. 1991, 62, 165-185. [CrossRef]

22. Freeman, B.D. Basis of Permeability/Selectivity Tradeoff Relations in Polymeric Gas Separation Membranes. Macromolecules 1999, 32, 375-380. [CrossRef]

23. Robeson, L.M. The upper bound revisited. J. Membr. Sci. 2008, 320, 390-400. [CrossRef]

24. Swaidan, R.; Ghanem, B.; Pinnau, I. Fine-Tuned Intrinsically Ultramicroporous Polymers Redefine the Permeability/Selectivity Upper Bounds of Membrane-Based Air and Hydrogen Separations. ACS Macro Lett. 2015, 4, 947-951. [CrossRef]

25. Comesaña-Gándara, B.; Chen, J.; Bezzu, C.G.; Carta, M.; Rose, I.; Ferrari, M.-C.; Esposito, E.; Fuoco, A.; Jansen, J.C.; McKeown, N.B. Redefining the Robeson upper bounds for $\mathrm{CO}_{2} / \mathrm{CH}_{4}$ and $\mathrm{CO}_{2} / \mathrm{N}_{2}$ separations using a series of ultrapermeable benzotriptycene-based polymers of intrinsic microporosity. Energy Environ. Sci. 2019, 12, 2733-2740. [CrossRef]

26. Budd, P.M.; Ghanem, B.S.; Makhseed, S.; McKeown, N.B.; Msayib, K.J.; Tattershall, C.E. Polymers of intrinsic microporosity (PIMs): Robust, solution-processable, organic nanoporous materials. Chem. Commun. (Cambridge, UK) 2004, 2, 230-231. [CrossRef]

27. Carta, M.; Bernardo, P.; Clarizia, G.; Jansen, J.C.; McKeown, N.B. Gas Permeability of Hexaphenylbenzene file Based Polymers of Intrinsic Microporosity. Macromolecules 2014, 47, 8320-8327. [CrossRef]

28. Bezzu, C.G.; Carta, M.; Tonkins, A.; Jansen, J.C.; Bernardo, P.; Bazzarelli, F.; McKeown, N.B. A Spirobifluorene-Based Polymer of Intrinsic Microporosity with Improved Performance for Gas Separation. Adv. Mater. 2012, 24, 5930-5933. [CrossRef]

29. Carta, M.; Croad, M.; Malpass-Evans, R.; Jansen, J.C.; Bernardo, P.; Clarizia, G.; Friess, K.; Lanč, M.; McKeown, N.B. Triptycene Induced Enhancement of Membrane Gas Selectivity for Microporous Tröger's Base Polymers. Adv. Mater. 2014, 26, 3526-3531. [CrossRef]

30. Fuoco, A.; Comesaña-Gándara, B.; Longo, M.; Esposito, E.; Monteleone, M.; Rose, I.; Bezzu, C.G.; Carta, M.; McKeown, N.B.; Jansen, J.C. Temperature Dependence of Gas Permeation and Diffusion in Triptycene-Based Ultrapermeable Polymers of Intrinsic Microporosity. ACS Appl. Mater. Interfaces 2018, 10, 36475-36482. [CrossRef]

31. Carta, M.; Malpass-Evans, R.; Croad, M.; Rogan, Y.; Lee, M.; Rose, I.; McKeown, N.B. The synthesis of microporous polymers using Troger's base formation. Polym. Chem. 2014, 5, 5267-5272. [CrossRef]

32. Carta, M.; Croad, M.; Jansen, J.C.; Bernardo, P.; Clarizia, G.; McKeown, N.B. Synthesis of cardo-polymers using Troger's base formation. Polym. Chem. 2014, 5, 5255-5261. [CrossRef]

33. Williams, R.; Burt, L.A.; Esposito, E.; Jansen, J.C.; Tocci, E.; Rizzuto, C.; Lanč, M.; Carta, M.; McKeown, N.B. A highly rigid and gas selective methanopentacene-based polymer of intrinsic microporosity derived from Tröger's base polymerization. J. Mater. Chem. A 2018, 6, 5661-5667. [CrossRef]

34. Rose, I.; Carta, M.; Malpass-Evans, R.; Ferrari, M.-C.; Bernardo, P.; Clarizia, G.; Jansen, J.C.; McKeown, N.B. Highly permeable benzotriptycene-based polymer of intrinsic microporosity. ACS Macro Lett. 2015, 4, 912-915. [CrossRef]

35. Carta, M.; Malpass-Evans, R.; Croad, M.; Rogan, Y.; Jansen, J.C.; Bernardo, P.; Bazzarelli, F.; McKeown, N.B. An Efficient Polymer Molecular Sieve for Membrane Gas Separations. Science 2013, 339, 303-307. [CrossRef] [PubMed] 
36. Bernardo, P.; Scorzafave, V.; Clarizia, G.; Tocci, E.; Jansen, J.C.; Borgogno, A.; Malpass-Evans, R.; McKeown, N.B.; Carta, M.; Tasselli, F. Thin film composite membranes based on a polymer of intrinsic microporosity derived from Tröger's base: A combined experimental and computational investigation of the role of residual casting solvent. J. Membr. Sci. 2019, 569, 17-31. [CrossRef]

37. Genduso, G.; Wang, Y.; Ghanem, B.S.; Pinnau, I. Permeation, sorption, and diffusion of $\mathrm{CO}_{2}-\mathrm{CH}_{4}$ mixtures in polymers of intrinsic microporosity: The effect of intrachain rigidity on plasticization resistance. J. Membr. Sci. 2019, 584, 100-109. [CrossRef]

38. Crank, J. The Mathematics of Diffusion, 2nd ed.; Oxford University Press: London, UK, 1975; p. 414.

39. Fraga, S.C.; Monteleone, M.; Lanč, M.; Esposito, E.; Fuoco, A.; Giorno, L.; Pilnáček, K.; Friess, K.; Carta, M.; McKeown, N.B.; et al. A novel time lag method for the analysis of mixed gas diffusion in polymeric membranes by on-line mass spectrometry: Method development and validation. J. Membr. Sci. 2018, 561, 39-58. [CrossRef]

40. Benito, J.; Sánchez-Laínez, J.; Zornoza, B.; Martín, S.; Carta, M.; Malpass-Evans, R.; Téllez, C.; McKeown, N.B.; Coronas, J.; Gascón, I. Ultrathin Composite Polymeric Membranes for $\mathrm{CO}_{2} / \mathrm{N}_{2}$ Separation with Minimum Thickness and High $\mathrm{CO}_{2}$ Permeance. ChemSusChem 2017, 10, 4014-4017. [CrossRef]

41. Tocci, E.; De Lorenzo, L.; Bernardo, P.; Clarizia, G.; Bazzarelli, F.; McKeown, N.B.; Carta, M.; Malpass-Evans, R.; Friess, K.; Pilnacek, K.; et al. Molecular Modeling and Gas Permeation Properties of a Polymer of Intrinsic Microporosity Composed of Ethanoanthracene and Troger's Base Units. Macromolecules 2014, 47, 7900-7916. [CrossRef]

42. Cristol, S.J.; Hause, N.L. Mechanisms of Elimination Reactions. V. Preparation and Elimination Reactions of cis- and trans-11,12-Dichloro-9,10-dihydro-9,10-ethanoanthracene1,2, 3. J. Am. Chem. Soc. 1952, 74, 2193-2197. [CrossRef]

43. Naghipur, A.; Reszka, K.; Sapse, A.M.; Lown, J.W. Formation of benzoxathiete under mild conditions and its valence tautomerism in solution to monothio-o-benzoquinone: An experimental and quantum chemical study. J. Am. Chem. Soc. 1989, 111, 258-268. [CrossRef]

44. Lanč, M.; Pilnáček, K.; Mason, C.R.; Budd, P.M.; Rogan, Y.; Malpass-Evans, R.; Carta, M.; Gándara, B.C.; McKeown, N.B.; Jansen, J.C.; et al. Gas sorption in polymers of intrinsic microporosity: The difference between solubility coefficients determined via time-lag and direct sorption experiments. J. Membr. Sci. 2019, 570-571, 522-536. [CrossRef]

45. Fuoco, A.; Rizzuto, C.; Tocci, E.; Monteleone, M.; Esposito, E.; Budd, P.M.; Carta, M.; Comesaña-Gándara, B.; McKeown, N.B.; Jansen, J.C. The origin of size-selective gas transport through polymers of intrinsic microporosity. J. Mater. Chem. A 2019, 7, 20121-20126. [CrossRef]

46. Teplyakov, V.; Meares, P. Correlation aspects of the selective gas permeabilities of polymeric materials and membranes. Gas Sep. Purif. 1990, 4, 66-74. [CrossRef] 